\title{
A technique for quantifying heterogeneous ice nucleation in microlitre supercooled water droplets
}

\author{
T. F. Whale ${ }^{1}$, B. J. Murray ${ }^{1}$, D. O’Sullivan ${ }^{1}$, T. W. Wilson ${ }^{1}$, N. S. Umo ${ }^{1}$, K. J. Baustian ${ }^{1}$, J. D. Atkinson ${ }^{1, *}$, \\ D. A. Workneh ${ }^{2}$, and G. J. Morris ${ }^{3}$ \\ ${ }^{1}$ School of Earth and Environment, University of Leeds, Leeds, LS2 9JT, UK \\ ${ }^{2}$ Department of Physics, Addis Ababa University, Addis Ababa, Ethiopia \\ ${ }^{3}$ Asymptote Ltd., St. John's Innovation Centre, Cowley Road, Cambridge, CB4 0WS, UK \\ * now at: Institute for Atmospheric and Climate Science, Universitaetstr. 16, ETH Zurich, Zurich, Switzerland \\ Correspondence to: T. F. Whale (eetfw@leeds.ac.uk) and B. J. Murray (b.j.murray@leeds.ac.uk)
}

Received: 28 August 2014 - Published in Atmos. Meas. Tech. Discuss.: 17 September 2014

Revised: 2 April 2015 - Accepted: 16 May 2015 - Published: 15 June 2015

\begin{abstract}
In many clouds, the formation of ice requires the presence of particles capable of nucleating ice. Icenucleating particles (INPs) are rare in comparison to cloud condensation nuclei. However, the fact that only a small fraction of aerosol particles can nucleate ice means that detection and quantification of INPs is challenging. This is particularly true at temperatures above about $-20^{\circ} \mathrm{C}$ since the population of particles capable of serving as INPs decreases dramatically with increasing temperature. In this paper, we describe an experimental technique in which droplets of microlitre volume containing ice-nucleating material are cooled down at a controlled rate and their freezing temperatures recorded. The advantage of using large droplet volumes is that the surface area per droplet is vastly larger than in experiments focused on single aerosol particles or cloud-sized droplets. This increases the probability of observing the effect of less common, but important, high-temperature INPs and therefore allows the quantification of their ice nucleation efficiency. The potential artefacts which could influence data from this experiment, and other similar experiments, are mitigated and discussed. Experimentally determined heterogeneous ice nucleation efficiencies for K-feldspar (microcline), kaolinite, chlorite, NX-illite, Snomax ${ }^{\circledR}$ and silver iodide are presented.
\end{abstract}

\section{Introduction}

Cloud droplets can supercool to temperatures below $-37^{\circ} \mathrm{C}$ (Rosenfeld and Woodley, 2000) but can freeze at much warmer temperatures in the presence of ice-nucleating particles (INPs). In fact, mixed-phase stratus clouds are observed to glaciate at temperatures warmer than $-15^{\circ} \mathrm{C}$, but only in certain locations (Kanitz et al., 2011). In addition, ice formation in the ice multiplication regime around -3 to $-8^{\circ} \mathrm{C}$ is critically important in the formation of precipitation from convective clouds (Crawford et al., 2012; Pruppacher and Klett, 1997). However, recent assessments of laboratory ice nucleation data for a range of atmospherically relevant materials concluded that it is unclear which aerosol species trigger freezing above $-15^{\circ} \mathrm{C}$ (Murray et al., 2012; Hoose and Möhler, 2012). Part of the problem is that many quantitative experimental techniques for determining ice nucleation efficiency are not sufficiently sensitive to quantify the efficiency of many nucleants at temperatures warmer than $-15^{\circ} \mathrm{C}$.

There are a number of instruments types that have been used for research into immersion mode ice nucleation, and reviews on the subject are available (Hoose and Möhler, 2012; Murray et al., 2012). These instruments include cloud chambers (e.g. Jiang et al., 2014; Niemand et al., 2012; Cotton et al., 2007), continuous-flow diffusion chambers (CFDCs; e.g. Salam et al., 2006; Rogers et al., 2001) and a wide variety of droplet-freezing experiments (e.g. Knopf and Alpert, 2013; Vali, 2008; Murray et al., 2011; Budke and Koop, 2015). Cloud chambers and CFDCs quantify the ice 
nucleation ability of a dispersion of aerosol particles as a function of relative humidity and temperature. In contrast, droplet-freezing experiments tend to have multiple particles suspended in individual water droplets.

A common way of quantifying the ice nucleation efficiency of a material is using the ice-active surface site density, $n_{\mathrm{s}}$, which is the cumulative number of nucleation sites per unit surface area of nucleant that become active on cooling from $0^{\circ} \mathrm{C}$ to a temperature $T$ (Connolly et al., 2009).

$\frac{n(T)}{N}=1-\exp \left(-n_{\mathrm{s}}(T) A\right)$,

where $n(T)$ is the number of droplets frozen at temperature $(T), N$ is the total number of droplets in the experiment and $A$ is the surface area of nucleant per droplet. In using this approximation it is assumed that the time dependence of nucleation arising from the stochastic nature of ice nucleation is negligible.

In general, instrumentation employing single aerosol particles suspended in gas and droplet experiments working with cloud-sized droplets (tens of micrometres) report values of $n_{\mathrm{s}}$ down to about $10^{3} \mathrm{~cm}^{-2}$ (e.g. see Fig. 18 of Murray et al., 2012, for a compilation). These measurements are clearly valuable and applicable to the atmosphere, but even smaller $n_{\mathrm{s}}$ values are also relevant (Murray et al., 2012). For example, if we consider a dust-influenced atmosphere with five dust particles per cubic centimetre with a mean radius of $500 \mathrm{~nm}$, then in order to generate 10 ice crystals per cubic metre an $n_{\mathrm{s}}$ of only $60 \mathrm{~cm}^{-2}$ would be required. Hence, it is important that we have the capacity to measure $n_{\mathrm{s}}$ smaller than $10^{3} \mathrm{~cm}^{-2}$ in addition to the capacity to measure larger values.

Our experimental approach builds on techniques employing aliquots of water much larger than the dimensions of typical cloud droplets which have been used since the very early days of ice nucleation studies (Vali, 1971, 1995) and continue to be used in the present day (Stopelli et al., 2014; Conen et al., 2011; Knopf and Forrester, 2011; Garcia et al., 2012; Budke and Koop, 2015). The advantage of this approach is that the surface area of nucleant per droplet scales with the volume of the droplet (for a constant mass fraction of nucleant in water). Hence, increasing the size of droplet from cloud droplet sizes ( $\sim 10 \mu \mathrm{m}$; picolitre) to $1 \mathrm{~mm}$ (microlitre) increases the surface area per droplet by 6 orders of magnitude. This allows the quantification of $n_{\mathrm{s}}$ to much smaller values than is possible using cloud-sized droplets.

The basic concept of a droplet-freezing experiment (or droplet-freezing assay) is to take an aqueous suspension and subdivide it into multiple aliquots of ideally identical volume; however, polydisperse droplet distributions can also be used (Vali, 1971; Murray et al., 2011). The multiple droplets are then cooled identically. Experiments can be conducted using a constant cooling rate (i.e. isothermally) or a stepped temperature profile, and they have differed widely in terms of droplet volume, droplet production and cooling method
(Vali, 1995). The fraction of droplets frozen at a given temperature or after a certain time interval can hence be determined. There are various methods of analysing the resultant data (Vali, 2014). These include deterministic models (such as Eq. 1) that link droplet fraction frozen directly to temperature (e.g. Vali, 1971) and time-dependent models of varying complexity (e.g. Marcolli et al., 2007; Herbert et al., 2014; Broadley et al., 2012).

In this paper, we present a method of conducting a dropletfreezing experiment using microlitre scale droplets. While the principle of the technique is not new, the specific application of the technique is, and the aim of this paper is to document the equipment, methods and analysis associated with the technique. Our instrument, the microlitre $\mathrm{Nu}-$ cleation by Immersed Particle Instrument ( $\mu$ l-NIPI), is based around a Stirling cryocooler which cools a hydrophobic surface that supports microlitre volume droplets. The freezing of the droplets is monitored using a digital camera. We present new data for the nucleation efficiency of K-feldspar (microcline), kaolinite, chlorite, NX-illite, Snomax ${ }^{\circledR}$ and silver iodide. This data is used to illustrate several potential freezing artefacts and how to avoid them.

\section{Description of the microlitre Nucleation by Immersed Particle Instrument}

The $\mu$ l-NIPI forms part of a suite of instruments which are designed to make measurements of $n_{\mathrm{s}}$ over 10 orders of magnitude, thus covering the range relevant for the atmosphere. We have previously described a droplet-freezing technique using picolitre volume droplets which has been used to study mineral dusts (Atkinson et al., 2013; Broadley et al., 2012; Murray et al., 2011), soil particles (O'Sullivan et al., 2014) and homogeneous nucleation (Murray et al., 2010), as well as a technique using nanolitre droplets with soil (O'Sullivan et al., 2014) and combustion ash particles (Umo et al., 2015). The microlitre technique described in detail here has been used to study ice nucleation by mineral dusts (Atkinson et al., 2013), soil (O'Sullivan et al., 2014), nanoscale INPs (O'Sullivan et al., 2015), combustion ash (Umo et al., 2015) and time dependence of nucleation by kaolinite and K-feldspar (Herbert et al., 2014). This instrument was also included in an intercomparison between 17 instruments (Hiranuma et al., 2015). The resulting $n_{\mathrm{s}}$ values for nx-illite were within 1 order of magnitude of other immersion mode instruments, whereas the cloud chamber and FRIDGE instruments report larger $n_{\mathrm{s}}$ values in the same temperature range. The causes for this discrepancy are not clear but are discussed by Hiranuma et al. (2015).

The $\mu l$-NIPI also offers a number of advantages over some other instruments: experiments can be performed relatively quickly; freezing events are easy to detect, and the continuous monitoring of freezing during a controlled temperature ramp allows the generation of a nucleation spectrum; and, in 


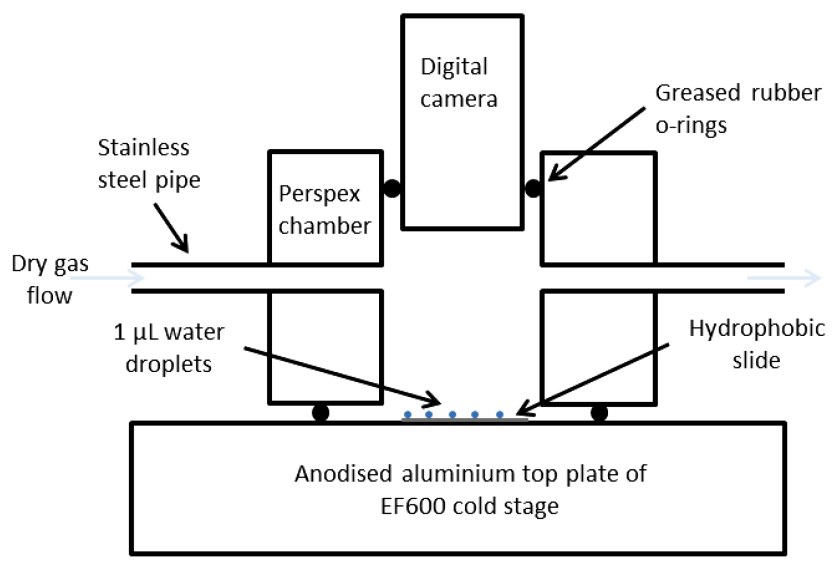

Figure 1. Diagram illustrating the key components of the $\mu$ L-NIPI.

addition, it has no need for cooling fluids and the equipment is portable, allowing it to be readily deployed in field settings.

The general layout of the $\mu$ l-NIPI is shown in Fig. 1. The $\mu \mathrm{l}$-NIPI consists of a cold stage, a hydrophobic surface which supports the droplets, an enclosure in which the humidity experienced by the droplets can be controlled and a digital camera to monitor the state of the droplets. To provide cooling and temperature monitoring, a Grant-Asymptote EF600 cold stage was employed. The EF600 was developed for the purpose of cooling samples for biological cryopreservation and can control the temperature of a sample between 20 and $-100{ }^{\circ} \mathrm{C}$. For cryopreservation, a top plate capable of holding multiple cryovials is typically employed. However, a flat aluminium top plate is also available and was used for this experimental setup. To conduct a droplet-freezing experiment, a $22 \mathrm{~mm}$ diameter hydrophobic silanised glass slide of $0.22 \mathrm{~mm}$ thickness (Hampton Research HR3-231) was placed onto this flat top plate. Prior to the experiments, the slide was cleaned using water, methanol and chloroform. Around 40 droplets of $1 \mu \mathrm{L}$ volume were pipetted onto the slide using a Picus Biohit electronic pipette while the slide was at room temperature. To ensure that individual droplets contained the same amount of material the suspensions were stirred during the pipetting process. The uncertainty in volume quoted by the manufacturer is $\pm 0.025 \mu \mathrm{L}$. The droplets and slide were then covered within a Perspex chamber with ports for a camera (Microsoft Lifecam HD) and stainlesssteel pipes for delivering a gas flow to the cell. A recessed rubber O-ring was used to seal the chamber to the EF600 cold stage and an O-ring is also used to seal the camera opening. Both O-rings were coated with vacuum grease. A flow of dry zero-grade nitrogen $\left(0.2 \mathrm{~L} \mathrm{~min}^{-1}\right)$ was passed through the cell in order to prevent frost growth (see discussion in Sect. 3.1).

The EF600 was internally controlled by a Eurotherm 2416 PID controller, run via Eurotherm's iTools control software. For all work presented here, this software was used to program and commence a $1{ }^{\circ} \mathrm{C} \mathrm{min}^{-1}$ temperature ramp from 1

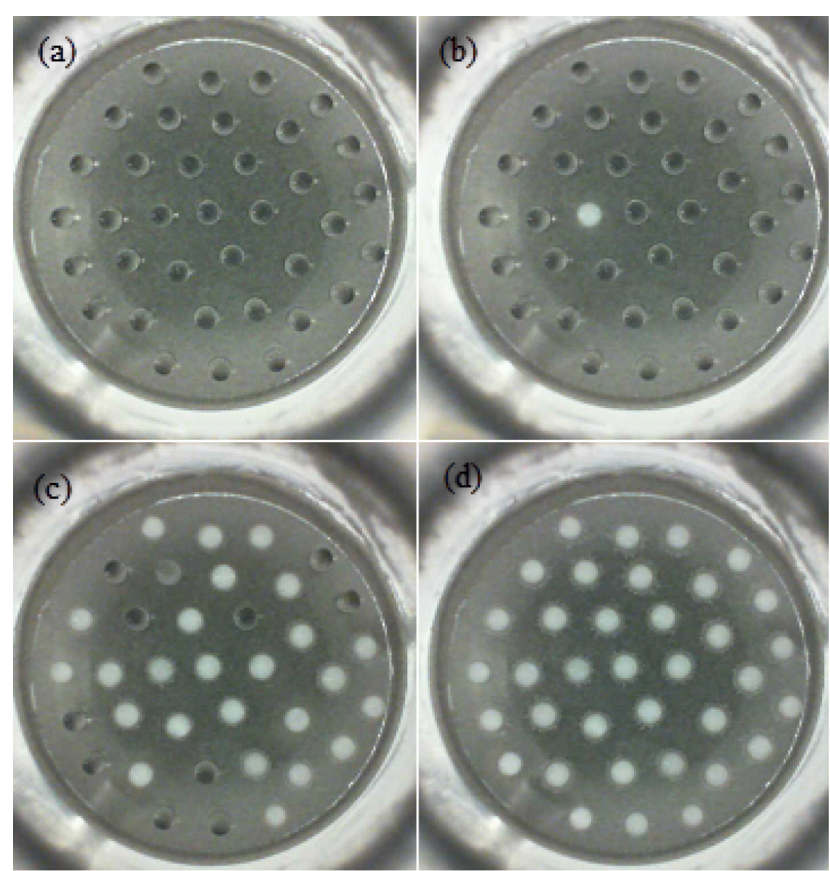

Figure 2. The progression of a $\mu$ l-NIPI freezing experiment. The experiment shown used a dispersion containing $0.01 \mathrm{wt} \% \mathrm{~K}$-feldspar. (a) was taken at around $-10^{\circ} \mathrm{C}$, shortly before the onset of freezing; (b) immediately after the first droplet had frozen; (c) at $-14^{\circ} \mathrm{C}$ and (d) at $-20^{\circ} \mathrm{C}$, after the completion of freezing. The top left of (c) shows a droplet in the process of freezing. Droplets of this size typically take 2-4s to freeze completely, proceeding much faster at lower temperatures. The initial change in the droplet leading to freezing is taken as the occurrence of ice nucleation.

to $-35^{\circ} \mathrm{C}$. Once the ramp was commenced, data logger software associated with the EF600 was started and used to produce a log of temperature against time. A LabView program was used to record an image series from the digital camera, typically at a rate of one frame per second, and to produce a timestamp for each frame. Hence, the temperature of the cold stage during each frame was known. Videos were reviewed frame by frame and the temperature of freezing of each droplet recorded. Stills from the digital camera at several stages in the freezing experiment are shown in Fig. 2. The first change in droplet structure leading to droplet freezing was taken to be the nucleation event, and this information was used to establish the fraction of droplets frozen as a function of temperature.

The EF600 has a quoted temperature uncertainty of $\pm 0.15^{\circ} \mathrm{C}$ at $-7^{\circ} \mathrm{C}$. To check the reliability of temperature measurement across a range of temperatures, a variety of compounds with known melting points were frozen and then melted by heating at $0.1^{\circ} \mathrm{C} \mathrm{min}-1$. The melting temperature range was determined visually. Results from this process are presented in Table 1. It is necessary to calibrate using melting points, rather than freezing points; crystallisation observed during cooling is always subject to nucleation, making them 
unsuitable for calibration of temperature unless the nucleation temperatures are very well defined (Riechers et al., 2013). By propagating the temperature error of the EF600 and the melting point range seen for water, a maximum temperature error of $\pm 0.4{ }^{\circ} \mathrm{C}$ has been estimated.

\subsection{Suspension preparation}

As in previous studies suspensions of solid material in MilliQ purified water $(18.2 \mathrm{M} \Omega \mathrm{cm})$ are made up gravimetrically and are then mixed using a magnetic stirrer plate overnight (Atkinson et al., 2013; O'Sullivan et al., 2014). In this study we used four mineral dusts (K-feldspar, kaolinite, chlorite and NX-illite), Snomax ${ }^{\circledR}$ (a commercial ice nucleant derived from Pseudomonas syringae bacteria) and silver iodide (details in Table 2). Mineralogies and other details are given in Table 2. The specific surface area of K-feldspar sample used was measured using the Brunauer-Emmett-Teller (BET) $\mathrm{N}_{2}$ adsorption method using a Micromeritics TriStar 3000. The data presented in Sect. 4 using these nucleants are to illustrate the utility of the $\mu \mathrm{l}$-NIPI and also illustrate potential artefacts the user should be aware of and how to avoid them. Uncertainty in surface area per droplet has been estimated at around $\pm 15 \%$ by propagating uncertainties in weighing of samples, the BET surface area and the volume error of the pipette.

\subsection{Control experiments}

Droplets on the microlitre scale are notoriously difficult to produce free of any heterogeneous INPs. For example, Langham and Mason (1958) recorded a median freezing temperature of around $-28^{\circ} \mathrm{C}$ for droplets of a volume on the order of a few microlitres and only occasionally saw drops reaching what is thought to be homogeneous nucleation temperatures $\left(\sim-33^{\circ} \mathrm{C}\right.$; Murray et al., 2010$)$ in a system that suspended water droplets between two liquids of different densities. This was despite the use of a complex distillation system to obtain high-purity water. To the best of our knowledge, only Fornea et al. (2009) have reported being able to reach the freezing temperatures predicted by CNT for microlitre volume droplets repeatedly, reporting an average freezing temperature of $-33.1 \pm 0.6^{\circ} \mathrm{C}$ for $2.0 \mu \mathrm{L}$ droplets of high-performance liquid chromatography water. Given the difficulty in producing microlitre droplets free of suspended INPs and surfaces free of ice-active sites or contaminants, it is necessary to establish the temperature limit below which freezing cannot be assumed to have been induced by a heterogeneous nucleant.

Freezing temperatures for Milli-Q water droplets are shown in Fig. 3. These droplets froze mostly between -20 and $-30^{\circ} \mathrm{C}$, substantially above the temperatures expected for homogeneous nucleation. Additionally, there is a $2-3^{\circ}$ spread in the freezing temperatures of separate experiments, which is larger than would be expected if the freezing pathway was homogeneous. We conclude that there are variable

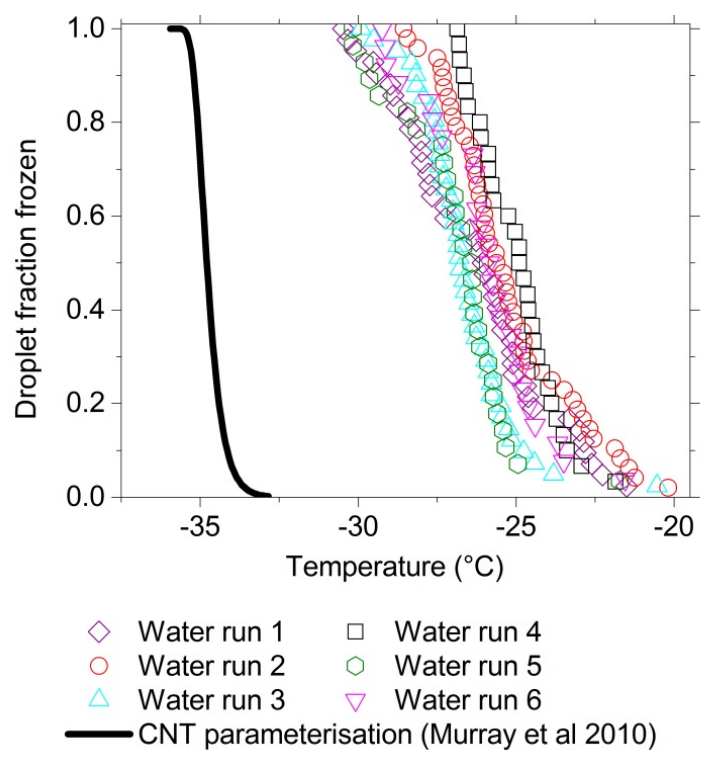

Figure 3. Temperature against fraction frozen for six different experiments using Milli-Q water. Also included is a line indicating the temperature of freezing expected for $1 \mu \mathrm{L}$ pure water droplets from classical nucleation theory $(\mathrm{CNT})$ according to the parameterisation by Murray et al. (2010).

quantities of heterogeneous ice-nucleating sites present that are active below about $-20^{\circ} \mathrm{C}$, but it is not clear if nucleation is occurring on the slide or on impurities in the water. MilliQ water is filtered through a $0.22 \mu \mathrm{m}$ filter and is specified to have less than one particle per millilitre larger than this size. However, no specification is provided for smaller particles. Impurities could also be introduced at points during the experimental procedure or from airborne particles in the laboratory. In light of these control experiments, $-20^{\circ} \mathrm{C}$ has been taken as the lower limit for most of the heterogenous ice nucleation experiments in this study.

\section{Discussion of potential artefacts and uses of droplet-freezing experiments}

Droplet-freezing experiments can suffer from a range of practical difficulties. This section addresses these problems and the solutions employed. As discussed by Stopelli et al. (2014), certain problems are encountered when using open droplet systems, where droplets are arranged on a hydrophobic surface, compared to closed droplet experiments, where each droplet is held in a separate container, or under inert oil. In an open droplet system, there is potential for droplets to evaporate over time, for contamination of droplets from airborne particles or for the freezing of droplets to influence neighbouring droplets by frost growth or splintering. As the $\mu \mathrm{l}$-NIPI is an open droplet system, these issues must be overcome. Closed droplet systems avoid some of these prob- 
Table 1. Melting points of solvents used to calibrate temperature of the $\mu$ l-NIPI. Recorded melting points are the average of five measurements. Literature melting points were taken from the 2007 CRC hand book.

\begin{tabular}{lrrrrrr}
\hline Chemical & $\begin{array}{r}\text { Literature melting } \\
\text { temperature }\left({ }^{\circ} \mathrm{C}\right)\end{array}$ & $\begin{array}{r}\text { Recorded melting } \\
\text { temperature }\left({ }^{\circ} \mathrm{C}\right)\end{array}$ & $\begin{array}{r}\text { Standard deviation } \\
\text { of melting point }\left({ }^{\circ} \mathrm{C}\right)\end{array}$ & $\begin{array}{r}\text { Start } \\
\left({ }^{\circ} \mathrm{C}\right)\end{array}$ & $\begin{array}{r}\text { Finish } \\
\left({ }^{\circ} \mathrm{C}\right)\end{array}$ & $\begin{array}{r}\text { Range } \\
\left({ }^{\circ} \mathrm{C}\right)\end{array}$ \\
\hline Dodecane & -9.57 & -9.5 & 0.09 & -9.7 & -9.3 & 0.4 \\
Octanol & -14.8 & -14.9 & 0.08 & -15.1 & -14.8 & 0.4 \\
Undecane & -25.5 & -25.4 & 0.10 & -25.7 & -25.3 & 0.4 \\
Water & 0.00 & 0.27 & 0.13 & -0.1 & 0.6 & 0.7 \\
\hline
\end{tabular}

Table 2. Characteristics of the materials used in this study. For silver iodide and Snomax ${ }^{\circledR}$ BET surface areas are not reported.

\begin{tabular}{|c|c|c|c|c|c|}
\hline Nucleant & $\begin{array}{l}\mathrm{N}_{2} \text { BET surface } \\
\text { area }\left(\mathrm{m}^{2} \mathrm{~g}^{-1}\right)\end{array}$ & Purity & Impurities & Supplier & Reference \\
\hline $\begin{array}{l}\text { K-feldspar } \\
\text { (microcline) }\end{array}$ & 1.86 & $78.1 \%$ & $\begin{array}{l}3.9 \% \text { quartz, } \\
16.0 \% \mathrm{Na} / \mathrm{Ca} \text { feldspar }\end{array}$ & $\begin{array}{l}\text { Bureau of Analysed } \\
\text { Samples, UK }\end{array}$ & Atkinson et al. (2013) \\
\hline KGa-1b kaolinite & 11.2 & $96 \%$ & $\begin{array}{l}\text { Crandallite, mica, } \\
\text { illite. anatase }\end{array}$ & Clay Mineral Society & $\begin{array}{l}\text { Chipera and Bish (2001); } \\
\text { Murrayet al. (2011) }\end{array}$ \\
\hline NX-illite & 104.2 & Mixed dust & - & Arginotec & $\begin{array}{l}\text { Hiranuma et al. (2015); } \\
\text { Broadley et al. (2012) }\end{array}$ \\
\hline Chlorite & 25.0 & $99.6 \%$ & unknown & $\begin{array}{l}\text { School of Earth } \\
\text { and Environment; } \\
\text { specimen collection }\end{array}$ & Atkinson et al. (2013) \\
\hline Silver iodide & - & $99.9999 \%$ & - & Alfa-Aesar premion & - \\
\hline Snomax ${ }^{\circledR}$ & - & - & - & York Snow Inc. & - \\
\hline
\end{tabular}

lems, but monitoring of freezing becomes more challenging as the droplets are not easily visible (Stopelli et al., 2014).

\subsection{Frost growth}

Early experiments on the apparatus were conducted without a flow of dry $\mathrm{N}_{2}$ over the droplets. This can cause significant issues when freezing of a droplet induces freezing in nearby droplets. Images of experiments with and without a dry flow of gas are shown in Fig. 4. In these experiments 10 droplets were seeded with silver iodide while the remainder were composed of pure water. When there was no flow of dry gas (panel b), there is extensive frost on the surface, which triggers freezing in neighbouring droplets; this artificially enhances the number of frozen droplets by $80 \%$ at $-12{ }^{\circ} \mathrm{C}$ in this case. Panel a shows an experiment conducted with a dry flow in which the seeded droplets froze at around $-5^{\circ} \mathrm{C}$, as expected, while the pure water droplets remained liquid down to below $-20^{\circ} \mathrm{C}$, indicating that with a dry flow there is no enhancement of freezing temperatures due to frost growth.

There are two distinct origins of the frost on the surface. Firstly, Jung et al. (2012) describe the formation of liquid condensation haloes, formed by the sudden increase in vapour pressure of water associated with the latent heat release of droplet freezing. They show that this halo can freeze if it persists. After freezing, subsequent frost growth

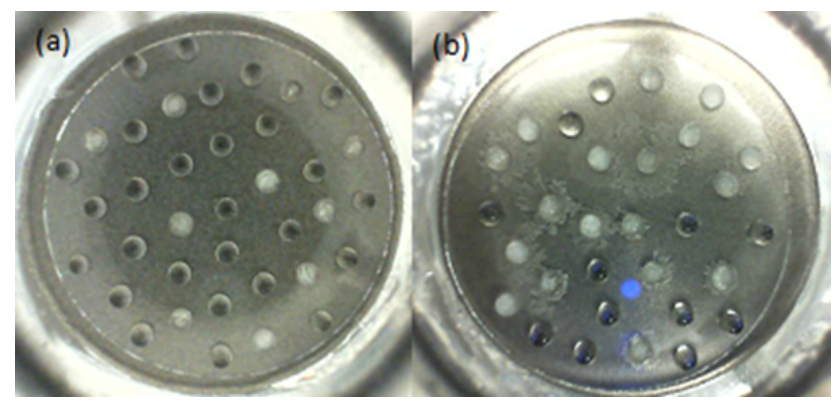

Figure 4. Examples of experiments conducted (a) with and (b) without a flow of dry nitrogen gas. (a) shows a single frame from an experiment where 10 droplets containing silver iodide were spread among droplets of pure water. A dry flow was employed to ensure ice growth did not take place. (b) shows a similar experiment where the dry flow was not employed and the resultant growth of ice across the slide which triggered freezing in pure water droplets. Both frames were taken at $-12{ }^{\circ} \mathrm{C}$.

directly from the vapour phase could come into contact with neighbouring droplets and trigger freezing in those droplets. Both of these effects have the potential to artificially increase the fraction frozen, and the problem will be most acute if the droplets freeze over a wide range of temperatures (our test with silver-iodide-containing droplets next to pure water droplets represents an extreme case). Our example illustrates 
that the use of a $0.2 \mathrm{~L} \mathrm{~min}^{-1}$ flow of dry gas eliminates the problems of frost haloes and frost growth. The condensation halo, consisting of very small droplets, evaporates rapidly in low-humidity conditions, and frost growth is reduced to the extent that it does not impact neighbouring droplets. Some small amount of frost growth is still observed in the immediate vicinity of a frozen droplet, taking the form of a very narrow ring around the droplet, but it does not extend far enough to interfere with neighbouring droplets. The flow of zero-grade nitrogen has the additional benefit that it flushes the chamber, reducing the chance of contact with aerosol particles from external sources.

\subsection{Droplet evaporation}

Using a dry flow as described in Sect. 3.1 has the potential to introduce additional issues. Droplets will evaporate to some extent through the course of the experiment (the extent will depend on the length of the experiment). This will increase the concentration of the contents of the droplets. Current descriptions of heterogeneous ice nucleation assume that the freezing temperature is dependent on the surface area of nucleant in a droplet, which will be constant despite evaporation. Therefore, it is assumed that changes in droplet volume will not affect experimental results. If solution droplets are being analysed, concentration changes due to droplet shrinkage will need to be accounted for as colligative effects will change the nucleation temperatures (Zobrist et al., 2008).

A second potential problem is that evaporation of water from droplets will cause cooling and may lead to the droplets being colder than the cold-stage temperature. In order to test for this evaporative cooling effect, a series of experiments was conducted both with and without the dry flow. Droplets containing 0.1 and $1 \mathrm{wt} \% \mathrm{~K}$-feldspar were tested with the dry flow switched on. They were then thawed and refrozen with the dry flow switched off. Figure 5 shows the results of this experiment. Freezing by K-feldspar is described well by a singular model (Herbert et al., 2014), suggesting that each droplet freezes with a repeatable characteristic temperature (Vali, 2008, 2014; Wright and Petters, 2013). Freezing temperatures did not shift, showing that the cooling effect of the dry flow is smaller than the temperature measurement uncertainty $\left( \pm 0.4^{\circ} \mathrm{C}\right)$. The small freezing temperature range of these experiments $\left(\sim 4^{\circ} \mathrm{C}\right)$ meant that frost growth from frozen droplets did not spread to neighbouring droplets even with the dry flow switched off.

\section{Test experiments and analysis}

Several example data sets are presented here to demonstrate the efficacy of the $\mu$ l-NIPI. The freezing temperatures for droplets containing K-feldspar (microcline), kaolinite, chlorite, Snomax ${ }^{\circledR}$ and silver iodide are shown in Fig. 6. The concentration of K-feldspar was varied between 0.01 and $1 \mathrm{wt} \%$,

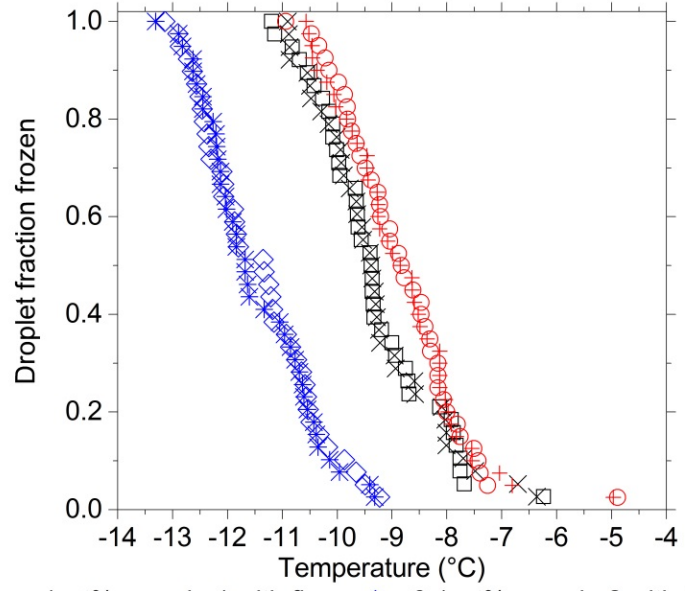

$1 \mathrm{wt} \%$ sample 1 with flow $\diamond 0.1 \mathrm{wt} \%$ sample 2 with flow

$1 \mathrm{wt} \%$ sample 1 no flow $* 0.1 \mathrm{wt} \%$ sample 2 no flow

- $1 \mathrm{wt} \%$ sample 1 with flow

$+1 \mathrm{wt} \%$ sample 1 no flow

Figure 5. Temperature against droplet fraction frozen with and without dry gas flowing over them. Four different sets of droplets containing K-feldspar were used. It can be seen that switching the dry flow on or off made no systematic difference to freezing temperatures.

and as expected the droplets containing more K-feldspar froze at a higher temperature. Droplets containing $1 \%$ chlorite and kaolinite froze at lower temperatures than droplets containing K-feldspar, which is consistent with Atkinson et al. (2013), who presented a case suggesting that K-feldspar is the most important mineral component of atmospheric mineral dusts.

Silver iodide is known to be capable of nucleating ice at high temperatures (DeMott, 1995; Vonnegut, 1947), and even with a mass concentration 100 times less than that of $1 \mathrm{wt} \%$ $\mathrm{K}$-feldspar it still nucleated ice at higher temperature. Interestingly, when a $0.1 \mathrm{wt} \%$ suspension was left on a windowsill for several days in a glass vial, the freezing temperature increased by around $2{ }^{\circ} \mathrm{C}$. There is a precedent for light exposure improving of the ice-nucleating ability of silver iodide in the literature, albeit in deposition mode rather than immersion mode (Rowland et al., 1964). There is also evidence from older work showing that light exposure can reduce the effectiveness of silver iodide as an ice nucleus (Fletcher, 1959; Smith et al., 1955). Further work is necessary to understand and quantify these effects.

Snomax ${ }^{\circledR}$ is a commercial preparation which contains fragments of a cultivated strain of Pseudomonas syringae and is used in the production of artificial snow at ski resorts (Cochet and Widehem, 2000). Droplets containing Snomax ${ }^{\circledR}$ nucleated ice around $-4{ }^{\circ} \mathrm{C}$ in this set of test experiments. Again, Snomax ${ }^{\circledR}$ is likely to exhibit variability in its ice nucleation activity between batches and individual samples depending on storage history; hence quantitative comparison with previous data is difficult. Nevertheless, Möhler 


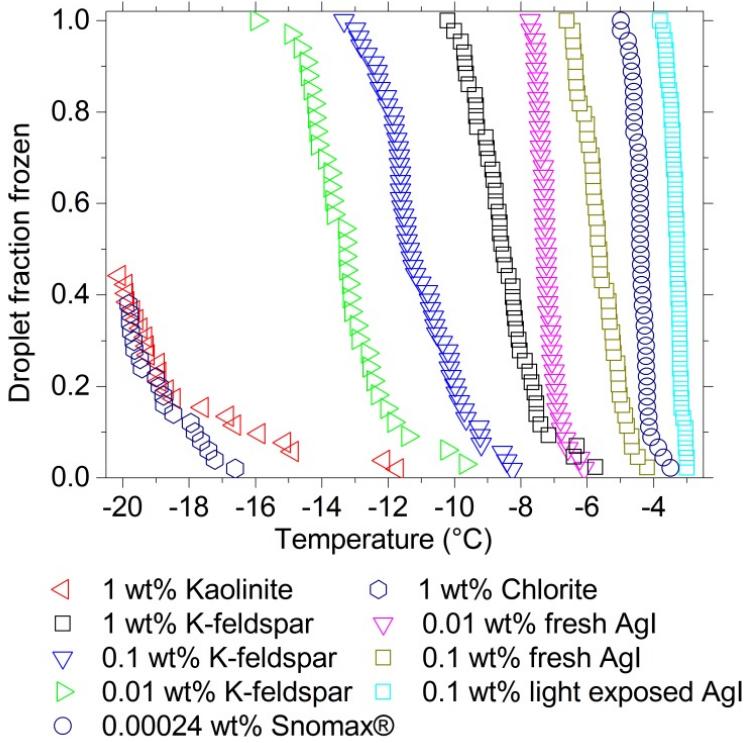

Figure 6. Temperature against fraction frozen for a variety of nucleants with a range of concentrations. The freezing temperature of droplets containing K-feldspar can be seen to steadily increase with increasing K-feldspar contamination.

et al. (2008) also report freezing by Snomax ${ }^{\circledR}$-containing droplets at very high temperatures, with about $1 \%$ of particles freezing at $-5.6^{\circ} \mathrm{C}$. Hartmann et al. (2013) observed freezing in Snomax ${ }^{\circledR}$-containing droplets at temperatures up to $-6^{\circ} \mathrm{C}$. Similarly, Wood et al. (2002) report freezing up to $-6^{\circ} \mathrm{C}$ in free-falling micron-scaled droplets containing Snomax ${ }^{\circledR}$. One feature reported in these previous studies is that the probability of freezing increases very steeply with decreasing temperature, which is again qualitatively consistent with our present measurements where the fraction frozen curve is extremely steep (Fig. 6). Recently, Wex et al. (2015) have published an extensive intercomparison of instruments using Snomax ${ }^{\circledR}$ as the test sample. The most similar instrument to $\mu$ L-NIPI intercompared, BINARY (Budke and Koop, 2015), gave qualitatively very similar results to those generated here at the most similar weight fraction tested. Our experiment $\left(2.4 \times 10^{-4} \mathrm{wt} \%\right)$ and those from from Wex et al. (2015) $\left(2.9 \times 10^{-4} \mathrm{wt} \%\right)$ both gave very steep fraction frozen curves at $-4^{\circ} \mathrm{C}$.

While droplet-freezing temperatures and fraction frozen data are useful for comparing ice nucleation abilities of different materials within the context of a single experimental setup, it is necessary to normalise the data to some measure of the amount of material per droplet, typically surface area (Murray et al., 2012). The resulting values of $n_{\mathrm{s}}$ are shown in Fig. 7, and we start this discussion with the data for K-feldspar. Over the three experiments the mineral surface area per droplet was varied by 2 orders of magnitude and the $n_{\mathrm{s}}$ values fall on a single line, and the data are in good agreement with our previous study by Atkinson et al. (2013).

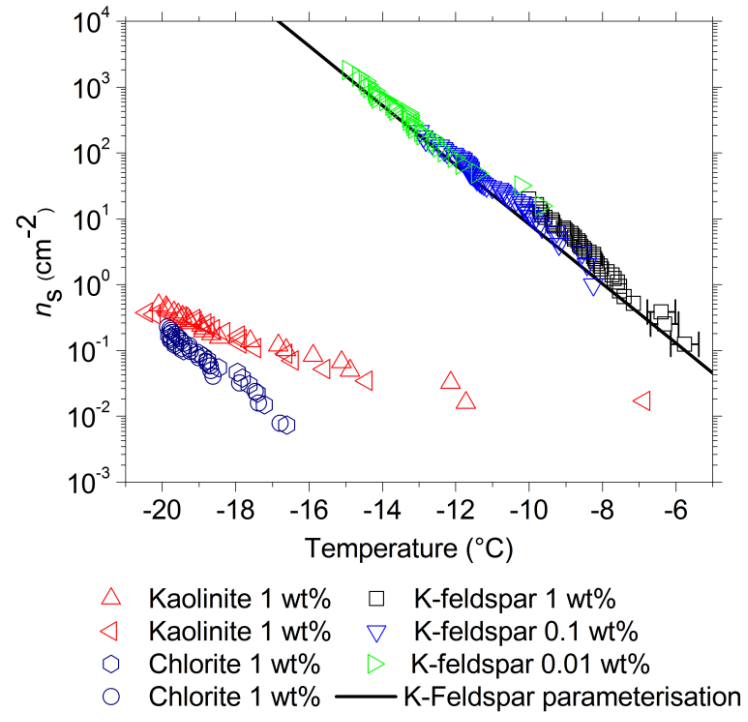

Figure 7. $n_{\mathrm{s}}$ values for K-feldspar, kaolinite and chlorite. Example temperature error bars are shown on the first three points of the $1 \mathrm{wt} \% \mathrm{~K}$-feldspar experiment. Estimated uncertainty in $n_{\mathrm{s}}$ due to uncertainty in the surface area of material per droplet is estimated at $\pm 15 \%$ and is too small to be shown on the chart. The K-feldspar parameterisation is from Atkinson et al. (2013).

Atkinson et al. (2013) produced this parameterisation for Kfeldspar through a combination of experiments with the $\mu \mathrm{L}-$ NIPI and pL-NIPI. The K-feldspar used in the present study is from the same stock sample used by Atkinson et al. (2013) but was ground separately and has a different specific surface area: $1.86 \mathrm{~m}^{2} \mathrm{~g}^{-1}$ rather than $3.15 \mathrm{~m}^{2} \mathrm{~g}^{-1}$ for the powder used by Atkinson et al. (2013). The chlorite and kaolinite $n_{\mathrm{S}}$ values are much lower than the K-feldspar values, as expected, and are consistent with the conclusions of Atkinson et al. (2013). The data in Fig. 7 also illustrate the reproducibility of the derived $n_{\mathrm{s}}$ values with this technique, with repeat runs for kaolinite and chlorite being identical within uncertainty.

By using relatively large droplets containing large surface areas of heterogeneous nucleants, higher freezing temperatures can be accessed using the $\mu \mathrm{L}-\mathrm{NIPI}$ than are possible in smaller-scale droplet-freezing experiments or techniques employing particles dispersed in gas. A consequence of this is very small amounts of a relatively efficient nucleant can dominate the ice-nucleating ability of a given sample. For instance, if an impurity in a material is 1000 times more active than the bulk material, i.e. its $n_{\mathrm{s}}$ is 1000 times higher than that of the bulk material, then the probability of freezing due to a $1 \mathrm{wt} \%$ contamination would be 10 times higher than of the bulk material and the impurity would dominate observed ice nucleation. This effect is illustrated in Fig. 8, where a sample containing a 60-times-larger surface area of kaolinite than K-feldspar is shown to nucleate ice at essentially the same temperatures that the K-feldspar component of the mixture would be expected to do. In this example it 


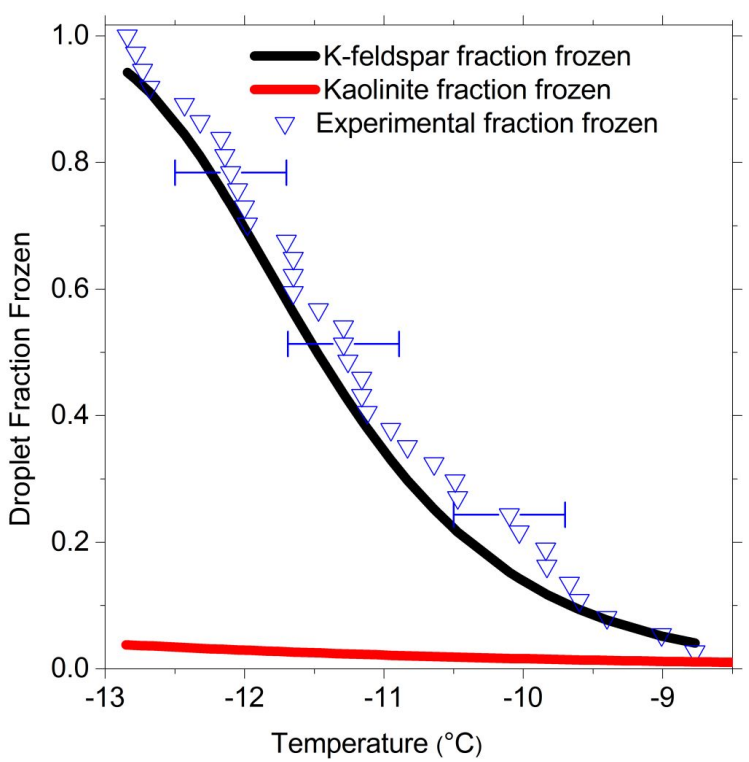

Figure 8. Fraction frozen for water droplets contaminated with $0.1 \mathrm{wt} \% \mathrm{~K}$-feldspar and $1 \mathrm{wt} \%$ kaolinite. For comparison the expected fractions calculated from parameterisations for $n_{\mathrm{s}}$ for relevant amounts of each material are included. In each droplet there is approximately 60 times more surface area of kaolinite than K-feldspar. Nevertheless, the experimental fraction frozen clearly tracks the fraction frozen calculated based upon the K-feldspar component. This demonstrates why it is important to quantify the precise composition of mineral dusts for ice nucleation measurements.

would easy to attribute the ice nucleation activity observed to kaolinite, when in fact it all comes from the feldspar "contaminant". If the aim of a study is to further fundamental understanding of ice nucleation by a particular material, it is important to recognise the potential impact of small impurities when working with larger droplets. While it is true that such an issue might also be observed with systems investigating smaller droplets, the smaller the amount of material in a droplet the less chance there is of a contaminating particle being present. Hence, there is a trade-off between measuring smaller $n_{\mathrm{s}}$ values and increasing the risk of contamination by minor components.

Some materials such as mineral dusts are known to aggregate when in aqueous suspension, and it has been hypothesised that this could lead to a reduced surface area and therefore underestimate in $n_{\mathrm{s}}$ (Hiranuma et al., 2015; Emersic et al., 2015). It is known that that aggregation of mineral dusts is concentration dependent (Emersic et al. 2015); hence reducing the dust concentration should reduce the impact on $n_{\mathrm{s}}$. In order to test if aggregation is affecting our measured $n_{\mathrm{s}}$, we have performed a sequence of experiments with NXillite suspensions of concentrations ranging from 0.005 to $2 \mathrm{wt} \%$ (see Fig. 9). It can be seen that the resulting $n_{\mathrm{s}}$ values are self-consistent, indicating that occlusion of surface by aggregation is not significant. Aggregates that do form

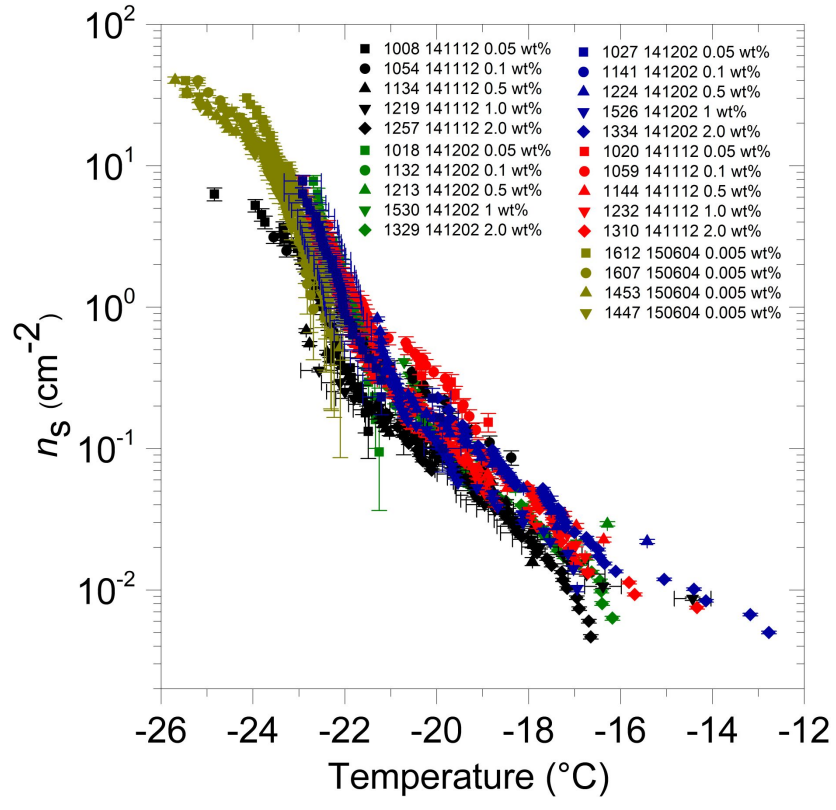

Figure 9. $n_{\mathrm{S}}$ values for $\mathrm{NX}$-illite determined from experiments with suspensions of a range of concentrations. Y-error bars have been calculated using the background subtraction method described in O'Sullivan et al. (2015), which includes the error propagation described in Sect. 2.1. X-error bars are included on certain data sets to facilitate comparison. 0.05 to $2 \mathrm{wt} \%$ suspensions were made gravimetrically, the $0.005 \mathrm{wt} \%$ suspensions were made by diluting $0.5 \mathrm{wt} \%$ suspensions.

are sufficiently porous that water can still reach all relevant surfaces of the dust. In addition, $n_{\mathrm{S}}$ for droplets containing $0.01-1 \mathrm{wt} \% \mathrm{~K}$-feldspar also falls on a single line (Fig. 7), suggesting that aggregation does not lead to the occlusion of surface area in K-feldspar either. Although aggregation does not affect $n_{\mathrm{s}}$ in these mineral dusts, it is worth bearing in mind that aggregation could conceivably reduce surface area in some nucleants, and it is therefore well worth testing for this by varying nucleant concentration and checking for consistency.

\section{Summary}

A new design of droplet-freezing experiment for ice nucleation experiments has been constructed and tested. The $\mu \mathrm{l}-$ NIPI uses a Stirling engine-based cryocooler to cool microlitre volume droplets at a controlled rate in order to determine the efficiency with which immersed particles nucleate ice. Many modern atmospheric ice nucleation measurement techniques measure the nucleation by aerosolised particles or particles suspended in cloud-sized droplets. The advantage of working with droplets much larger than cloud droplets is that they contain a far larger surface area of nucleant. This allows the determination of nucleation efficiencies over a wider range of temperatures than is possible using 
only smaller droplets and complements the flowing aerosol and cloud-sized droplet techniques in widespread use.

In most ice nucleation experiments, efficient minor components in samples can dominate observed results, meaning that great care is needed in interpretation of results. While this is particularly true for experiments using such relatively large amounts of sample as the technique presented here, the ability to detect the activity of relatively rare, hightemperature ice nucleation events is valuable. The $\mu \mathrm{l}-\mathrm{NIPI}$ may be particularly useful in a field setting, where its low detection limit and simplicity of operation offer advantages over, and complementarity to, more complex instruments.

Acknowledgements. We gratefully acknowledge the Natural Environment Research Council (NERC, NE/I013466/1; NE/I020059/1; NE/I019057/1), the European Research Council (FP7, 240449 ICE) and Asymptote Ltd. for funding.

Edited by: A. Wiedensohler

\section{References}

Atkinson, J. D., Murray, B. J., Woodhouse, M. T., Whale, T. F., Baustian, K. J., Carslaw, K. S., Dobbie, S., O'Sullivan, D., and Malkin, T. L.: The importance of feldspar for ice nucleation by mineral dust in mixed-phase clouds, Nature, 498, 355-358, doi:10.1038/nature12278, 2013.

Broadley, S. L., Murray, B. J., Herbert, R. J., Atkinson, J. D., Dobbie, S., Malkin, T. L., Condliffe, E., and Neve, L.: Immersion mode heterogeneous ice nucleation by an illite rich powder representative of atmospheric mineral dust, Atmos. Chem. Phys., 12, 287-307, doi:10.5194/acp-12-287-2012, 2012.

Budke, C. and Koop, T.: BINARY: an optical freezing array for assessing temperature and time dependence of heterogeneous ice nucleation, Atmos. Meas. Tech., 8, 689-703, doi:10.5194/amt-8689-2015, 2015.

Chipera, S. J. and Bish, D. L.: Baseline studies of the clay minerals society source clays: powder x-ray diffraction analyses, Clay. Clay Miner., 49, 398-409, doi:10.1346/ccmn.2001.0490507, 2001.

Cochet, N. and Widehem, P.: Ice crystallization by pseudomonas syringae, Appl. Microbiol. Biot., 54, 153-161, doi:10.1007/s002530000377, 2000.

Conen, F., Morris, C. E., Leifeld, J., Yakutin, M. V., and Alewell, C.: Biological residues define the ice nucleation properties of soil dust, Atmos. Chem. Phys., 11, 9643-9648, doi:10.5194/acp-119643-2011, 2011.

Connolly, P. J., Möhler, O., Field, P. R., Saathoff, H., Burgess, R., Choularton, T., and Gallagher, M.: Studies of heterogeneous freezing by three different desert dust samples, Atmos. Chem. Phys., 9, 2805-2824, doi:10.5194/acp-9-2805-2009, 2009.

Cotton, R. J., Benz, S., Field, P. R., Möhler, O., and Schnaiter, M.: Technical Note: A numerical test-bed for detailed ice nucleation studies in the AIDA cloud simulation chamber, Atmos. Chem. Phys., 7, 243-256, doi:10.5194/acp-7-243-2007, 2007.

Crawford, I., Bower, K. N., Choularton, T. W., Dearden, C., Crosier, J., Westbrook, C., Capes, G., Coe, H., Connolly, P. J., Dorsey,
J. R., Gallagher, M. W., Williams, P., Trembath, J., Cui, Z., and Blyth, A.: Ice formation and development in aged, wintertime cumulus over the UK: observations and modelling, Atmos. Chem. Phys., 12, 4963-4985, doi:10.5194/acp-12-4963-2012, 2012.

DeMott, P. J.: Quantitative descriptions of ice formation mechanisms of silver iodide-type aerosols, Atmos. Res., 38, 63-99, doi:10.1016/0169-8095(94)00088-U, 1995.

Emersic, C., J. Connolly, P., Boult, S., Campana, M., and Li, Z.: Investigating the discrepancy between wet-suspension and drydispersion derived ice nucleation efficiency of mineral particles, Atmos. Chem. Phys. Discuss., 15, 887-929, doi:10.5194/acpd15-887-2015, 2015.

Fletcher, N. H.: A descriptive theory of the photo de-activation of silver iodide as an ice-crystal nucleus, J. Meteorol., 16, 249255, doi:10.1175/1520-0469(1959)016<0249:Adtotp>2.0.Co;2, 1959.

Fornea, A. P., Brooks, S. D., Dooley, J. B., and Saha, A.: Heterogeneous freezing of ice on atmospheric aerosols containing ash, soot, and soil, J. Geophys. Res.-Atmos., 114, D13201, doi:10.1029/2009jd011958, 2009.

Garcia, E., Hill, T. C. J., Prenni, A. J., DeMott, P. J., Franc, G. D., and Kreidenweis, S. M.: Biogenic ice nuclei in boundary layer air over two U. S. High plains agricultural regions, J. Geophys. Res.-Atmos., 117, D18209, doi:10.1029/2012jd018343, 2012.

Hartmann, S., Augustin, S., Clauss, T., Wex, H., Šantl-Temkiv, T., Voigtländer, J., Niedermeier, D., and Stratmann, F.: Immersion freezing of ice nucleation active protein complexes, Atmos. Chem. Phys., 13, 5751-5766, doi:10.5194/acp-13-57512013, 2013.

Herbert, R. J., Murray, B. J., Whale, T. F., Dobbie, S. J., and Atkinson, J. D.: Representing time-dependent freezing behaviour in immersion mode ice nucleation, Atmos. Chem. Phys., 14, 85018520, doi:10.5194/acp-14-8501-2014, 2014.

Hiranuma, N., Augustin-Bauditz, S., Bingemer, H., Budke, C., Curtius, J., Danielczok, A., Diehl, K., Dreischmeier, K., Ebert, M., Frank, F., Hoffmann, N., Kandler, K., Kiselev, A., Koop, T., Leisner, T., Möhler, O., Nillius, B., Peckhaus, A., Rose, D., Weinbruch, S., Wex, H., Boose, Y., DeMott, P. J., Hader, J. D., Hill, T. C. J., Kanji, Z. A., Kulkarni, G., Levin, E. J. T., McCluskey, C. S., Murakami, M., Murray, B. J., Niedermeier, D., Petters, M. D., O’Sullivan, D., Saito, A., Schill, G. P., Tajiri, T., Tolbert, M. A., Welti, A., Whale, T. F., Wright, T. P., and Yamashita, K.: A comprehensive laboratory study on the immersion freezing behavior of illite NX particles: a comparison of 17 ice nucleation measurement techniques, Atmos. Chem. Phys., 15, 2489-2518, doi:10.5194/acp-15-2489-2015, 2015.

Hoose, C. and Möhler, O.: Heterogeneous ice nucleation on atmospheric aerosols: a review of results from laboratory experiments, Atmos. Chem. Phys., 12, 9817-9854, doi:10.5194/acp-12-98172012, 2012.

Jiang, H., Yin, Y., Yang, L., Yang, S., Su, H., and Chen, K.: The characteristics of atmospheric ice nuclei measured at different altitudes in the huangshan mountains in southeast china, Adv. Atmos. Sci., 31, 396-406, doi:10.1007/s00376-013-3048-5, 2014.

Jung, S., Tiwari, M. K., and Poulikakos, D.: Frost halos from supercooled water droplets, P. Natl. Acad. Sci. USA, 109, 1607316078, doi:10.1073/pnas.1206121109, 2012.

Kanitz, T., Seifert, P., Ansmann, A., Engelmann, R., Althausen, D., Casiccia, C., and Rohwer, E. G.: Contrasting the impact 
of aerosols at northern and southern midlatitudes on heterogeneous ice formation, Geophys. Res. Lett., 38, L17802, doi:10.1029/2011g1048532, 2011.

Knopf, D. A. and Alpert, P. A.: A water activity based model of heterogeneous ice nucleation kinetics for freezing of water and aqueous solution droplets, Faraday Discuss., 165, 513-534, doi:10.1039/c3fd00035d, 2013.

Knopf, D. A. and Forrester, S. M.: Freezing of water and aqueous nacl droplets coated by organic monolayers as a function of surfactant properties and water activity, J. Phys. Chem. A, 115, 5579-5591, doi:10.1021/jp2014644, 2011.

Langham, E. J. and Mason, B. J.: The heterogeneous and homogeneous nucleation of supercooled water, P. R. Soc. Lond. A, 247, 493-504, doi:10.1098/rspa.1958.0207, 1958.

Marcolli, C., Gedamke, S., Peter, T., and Zobrist, B.: Efficiency of immersion mode ice nucleation on surrogates of mineral dust, Atmos. Chem. Phys., 7, 5081-5091, doi:10.5194/acp-7-50812007, 2007.

Möhler, O., Georgakopoulos, D. G., Morris, C. E., Benz, S., Ebert, V., Hunsmann, S., Saathoff, H., Schnaiter, M., and Wagner, R.: Heterogeneous ice nucleation activity of bacteria: new laboratory experiments at simulated cloud conditions, Biogeosciences, 5, 1425-1435, doi:10.5194/bg-5-1425-2008, 2008.

Murray, B. J., Broadley, S. L., Wilson, T. W., Bull, S. J., Wills, R. H., Christenson, H. K., and Murray, E. J.: Kinetics of the homogeneous freezing of water, Phys. Chem. Chem. Phys., 12, 1038010387, doi:10.1039/c003297b, 2010.

Murray, B. J., Broadley, S. L., Wilson, T. W., Atkinson, J. D., and Wills, R. H.: Heterogeneous freezing of water droplets containing kaolinite particles, Atmos. Chem. Phys., 11, 4191-4207, doi:10.5194/acp-11-4191-2011, 2011.

Murray, B. J., O’Sullivan, D., Atkinson, J. D., and Webb, M. E.: Ice nucleation by particles immersed in supercooled cloud droplets, Chem. Soc. Rev., 41, 6519-6554, doi:10.1039/C2CS35200A, 2012.

Niemand, M., Möhler, O., Vogel, B., Vogel, H., Hoose, C., Connolly, P., Klein, H., Bingemer, H., DeMott, P. J., Skrotzki, J., and Leisner, T.: A particle-surface-area-based parameterization of immersion freezing on desert dust particles, J. Atmos. Sci., 69, 3077-3092, doi:10.1175/jas-d-11-0249.1, 2012.

O'Sullivan, D., Murray, B. J., Malkin, T. L., Whale, T. F., Umo, N. S., Atkinson, J. D., Price, H. C., Baustian, K. J., Browse, J., and Webb, M. E.: Ice nucleation by fertile soil dusts: relative importance of mineral and biogenic components, Atmos. Chem. Phys., 14, 1853-1867, doi:10.5194/acp-14-18532014, 2014.

O'Sullivan, D., Murray, B. J., Ross, J. F., Whale, T. F., Price, H. C., Atkinson, J. D., Umo, N. S., and Webb, M. E.: The relevance of nanoscale biological fragments for ice nucleation in clouds, Sci. Rep., 5, 8082 doi:10.1038/srep08082, 2015.

Pruppacher, H. R. and Klett, J. D.: Microphysics of clouds and precipitation, 2nd Edn., Kluwer Academic Publishers, Dordrecht, the Netherlands, 1997.

Riechers, B., Wittbracht, F., Hütten, A., and Koop, T.: The homogeneous ice nucleation rate of water droplets produced in a microfluidic device and the role of temperature uncertainty, Phys. Chem. Chem. Phys., 15, 5873-5887, doi:10.1039/C3CP42437E, 2013.
Rogers, D. C., DeMott, P. J., Kreidenweis, S. M., and Chen, Y. L.: A continuous-flow diffusion chamber for airborne measurements of ice nuclei, J. Atmos. Ocean. Tech., 18, 725741, doi:10.1175/1520-0426(2001)018<0725:Acfdcf >2.0.Co;2, 2001.

Rosenfeld, D., and Woodley, W. L.: Deep convective clouds with sustained supercooled liquid water down to $-37.5^{\circ} \mathrm{C}$, Nature, 405, 440-442, doi:10.1038/35013030, 2000.

Rowland, S. C., Layton, R. G., and Smith, D. R.: Photolytic activation of silver iodide in the nucleation of ice, J. Atmos. Sci., 21, 698-700, doi:10.1175/15200469(1964)021<0698:paosii>2.0.co;2, 1964.

Salam, A., Lohmann, U., Crenna, B., Lesins, G., Klages, P., Rogers, D., Irani, R., MacGillivray, A., and Coffin, M.: Ice nucleation studies of mineral dust particles with a new continuous flow diffusion chamber, Aerosol Sci. Tech., 40, 134-143, doi:10.1080/02786820500444853, 2006.

Smith, E. J., Heffernan, K. J., and Seely, B. K.: The decay of ice-nucleating properties of silver iodide in the atmosphere, J. Meteorol., 12, 379-385, doi:10.1175/15200469(1955)012<0379:Tdoinp>2.0.Co;2, 1955.

Stopelli, E., Conen, F., Zimmermann, L., Alewell, C., and Morris, C. E.: Freezing nucleation apparatus puts new slant on study of biological ice nucleators in precipitation, Atmos. Meas. Tech., 7, 129-134, doi:10.5194/amt-7-129-2014, 2014.

mo, N. S., Murray, B. J., Baeza-Romero, M. T., Jones, J. M., LeaLangton, A. R., Malkin, T. L., O'Sullivan, D., Neve, L., Plane, J. M. C., and Williams, A.: Ice nucleation by combustion ash particles at conditions relevant to mixed-phase clouds, Atmos. Chem. Phys., 15, 5195-5210, doi:10.5194/acp-15-5195-2015, 2015.

Vali, G.: Quantitative evaluation of experimental results an the heterogeneous freezing nucleation of supercooled liquids, J. Atmos. Sci., 28, 402-409, doi:10.1175/15200469(1971)028<0402:qeoera>2.0.co;2, 1971.

Vali, G.: Principles of Ice Nucleation, Biological Ice Nucleation and its Applications, edited by: Lee Jr., R. E., Warren, G. J., and Gusta, L. V., American Phytopathological Society (APS) Press, Minnesota, USA, 1-28, 1995.

Vali, G.: Repeatability and randomness in heterogeneous freezing nucleation, Atmos. Chem. Phys., 8, 5017-5031, doi:10.5194/acp-8-5017-2008, 2008.

Vali, G.: Interpretation of freezing nucleation experiments: singular and stochastic; sites and surfaces, Atmos. Chem. Phys., 14, 5271-5294, doi:10.5194/acp-14-5271-2014, 2014.

Vonnegut, B.: The nucleation of ice formation by silver iodide, J. Appl. Phys., 18, 593-595, doi:10.1063/1.1697813, 1947.

Wex, H., Augustin-Bauditz, S., Boose, Y., Budke, C., Curtius, J., Diehl, K., Dreyer, A., Frank, F., Hartmann, S., Hiranuma, N., Jantsch, E., Kanji, Z. A., Kiselev, A., Koop, T., Möhler, O., Niedermeier, D., Nillius, B., Rösch, M., Rose, D., Schmidt, C., Steinke, I., and Stratmann, F.: Intercomparing different devices for the investigation of ice nucleating particles using Snomax ${ }^{\circledR}$ as test substance, Atmos. Chem. Phys., 15, 14631485, doi:10.5194/acp-15-1463-2015, 2015.

Wood, S. E., Baker, M. B., and Swanson, B. D.: Instrument for studies of homogeneous and heterogeneous ice nucleation in freefalling supercooled water droplets, Rev. Sci. Instrum., 73, 39883996, doi:10.1063/1.1511796, 2002. 
Wright, T. P. and Petters, M. D.: The role of time in heterogeneous freezing nucleation, J. Geophys. Res.-Atmos., 118, 3731-3743, doi:10.1002/jgrd.50365, 2013.
Zobrist, B., Marcolli, C., Peter, T., and Koop, T.: Heterogeneous ice nucleation in aqueous solutions: the role of water activity, $\mathrm{J}$. Phys. Chem. A, 112, 3965-3975, doi:10.1021/jp7112208, 2008. 